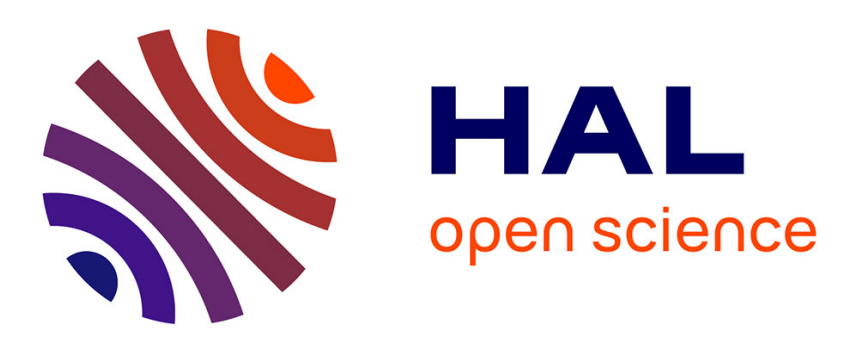

\title{
Activated Stat Related Transcription Factors in Acute Leukemia
}

Valérie Gouilleux-Gruart, Françoise Debierre-Grockiego, Fabrice Gouilleux, Jean-Claude Capiod, Jean-François Claisse, Jacques Delobel, Lionel Prin

\section{To cite this version:}

Valérie Gouilleux-Gruart, Françoise Debierre-Grockiego, Fabrice Gouilleux, Jean-Claude Capiod, Jean-François Claisse, et al.. Activated Stat Related Transcription Factors in Acute Leukemia. Leukemia \& lymphoma, 1997, 28 (1-2), pp.83-88. 10.3109/10428199709058334 . hal-02427398

\section{HAL Id: hal-02427398 \\ https: / hal-univ-tours.archives-ouvertes.fr/hal-02427398}

Submitted on 5 Nov 2021

HAL is a multi-disciplinary open access archive for the deposit and dissemination of scientific research documents, whether they are published or not. The documents may come from teaching and research institutions in France or abroad, or from public or private research centers.
L'archive ouverte pluridisciplinaire HAL, est destinée au dépôt et à la diffusion de documents scientifiques de niveau recherche, publiés ou non, émanant des établissements d'enseignement et de recherche français ou étrangers, des laboratoires publics ou privés. 


\title{
Activated Stat Related Transcription Factors in Acute Leukemia
}

\author{
VALÉRIE GOUILLEUX-GRUART *, FRANÇOISE DEBIERRE-GROCKIEGO, FABRICE GOUILLEUX, \\ JEAN-CLAUDE CAPIOD, JEAN-FRANÇOIS CLAISSE, JACQUES DELOBEL and LIONEL PRIN \\ Laboratoire d' Immunologie and Laboratoire d' Hématologie, Centre Hospitalier Universitaire d'Amiens, \\ Place Victor Pauchet. 80054 Amiens cedex 1, France
}

(In final form 17 February 1997)

\begin{abstract}
Cell proliferation and differentiation are under the control of cytokines and growth factors. Different signaling pathways are involved in the transmission of a specific signal through successive phosphorylation and dephosphorylation of proteins leading to gene transcription necessary for growth and differentiation. The cytokines and growth factors activate the Stat family of transcription factors. The Jak-Stat pathway is essential for cytokine signal transduction. Dysregulation of this cascade might lead to uncontrolled hematopoiesis. Studies have been carried out to examine the functionality of this pathway in cells from patients with acute leukemia. Members of the Stat protein family (Stat1, Stat3 and Stat5) are constitutively activated in cells collected from some acute leukemias suggesting dysregulation of the Jak-Stat pathway. Evidence of the existence of constitutively activated spliced variants of Stat 3 and Stat5 proteins are described. The mechanisms of such activation remain to be clarified.
\end{abstract}

Keywords: Leukemia, stat, constitutive activation, spliced variant

\section{INTRODUCTION}

Stat proteins (Signal Transducer and Activator of Transcription) are transcription factors involved in cytokines, growth factors and hormones signaling pathway. To date, seven different members of the Stat protein family have been cloned. ${ }^{[1-10]}$ The general mechanism leading to Stat activation is now well described. Cytokine binding to its receptor leads to the tyrosine phosphorylation of the associated protein tyrosine kinases of the Jak family. Activated Jak kinases induce the phosphorylation of cytoplasmic Stat molecules that subsequently dimerize and are translocated to the cell nucleus where they bind to specific DNA sequences and activate the transcription of target genes. ${ }^{[11-16]}$

Members of the Stat family vary in size from 734 to 851 amino acids. Sequence comparison of Stat identified homology boxes that led to the hallmarks for members of this family of proteins. The most highly conserved region is the SH2 (Src Homology 2) domain that is localized in the carboxyl half part of the protein.

* Corresponding author. Tel.: (33)3 226684 99. Fax: (33)3 22668494. 
SH2 domains are involved in the binding of phosphotyrosine residue interaction between the $\mathrm{SH} 2$ domain of one molecule and the phosphorylated site of another molecule. This mechanism participate to homo or heterodimerization of the Stat molecules. ${ }^{[16,17]}$ The SH2 domain is also involved in the recruitment of the Stat proteins to cytokine receptor complexes. ${ }^{[9,18,19]}$ The conserved amino-terminal domain of Stat proteins is required for cooperative DNA binding (tetramerization of the Stat molecules). Cooperative binding interactions enabled the Stat proteins to recognize variations of the consensus site. ${ }^{[20]}$ Between this domain and the $\mathrm{SH} 2$ domain is localized a region that carries the DNA binding specificity of the Stat molecules. This DNA binding region does not share any homology with known DNA binding domain. ${ }^{[21]}$ Another interesting region within amino acid sequences of Stat proteins is located at the carboxyl terminal end of the protein. This region varies in length and in amino acid composition among Stat family members. Spliced variants of Stat 1 , Stat 3 (respectively referred as Stat $1 \beta$, Stat $3 \beta$ ), Stat 5 a and Stat5b that lack the carboxyl-terminal amino acids have been cloned from different tissues and cells. ${ }^{[2,22,23]}$ Stat $1 \beta$ binds to DNA but is unable to activate interferon-induced Stat1 dependent genes. ${ }^{[24]}$ Deletion of the carboxyl-terminal transactivation domain of Stat5a and Stat5b results in sustained DNA-binding and in a dominant negative phenotype. ${ }^{[25]}$ Similar results have been reported for Stat5a and Stat5b natural spliced variants. ${ }^{[23]}$ These data indicate that the carboxyl-terminal region of Stat molecules contains an important domain for the modulation of the transcriptional and DNA binding activities of Stat proteins.

Stat protein activation has been described in a wide range of models including cell proliferation and differentiation processes. It has also been involved in activation of immunocompetent cells. For example, the activation of Stat signaling pathway has been studied in a primary T-cell response, ${ }^{[26]}$ in the inhibition of IFN $\gamma$ induced transcription of the Fc $\gamma$ RI gene in human monocytes by IgG immune complexes ${ }^{[27]}$ or in the differentiation of Th1 and Th2 like helper T-cells. ${ }^{[28]}$ The crucial role of the Jak-Stat pathway in proliferation, differentiation and activation has been pointed out in the development of various diseases. Several studies have been performed showing the activation of Stat proteins in pathologies related or not to cytokine overexpression. Activation of Stat proteins was found in cells from joint effusion of patients with inflammatory arthritis, ${ }^{[29]}$ in neuronal injury, ${ }^{[30]}$ in allergic reactions in skin diseases ${ }^{[31]}$ and in carcinoma or leukemia. ${ }^{[32-35]}$

\section{STAT PROTEINS AND ACUTE LEUKEMIA}

The production of cytokines and growth factors by leukemic cells and their proliferation without exogenous cytokines suggest a probable implication of a paracrine and/or autocrine growth regulation. Cytokines and growth factors have been shown to activate the Jak-Stat pathway and aberrations in this mechanism might play a role in leukemogenesis. The observation that Stat proteins are constitutively phosphorylated in cells transformed by the various oncoproteins such as v-src, v-abl or v-mpl suggests that Stat proteins could play a role in cell transformation. ${ }^{[36-39]}$ The involvement of the Jak-Stat pathway was also described in the leukemia like hematopoietic defect caused by an amino acid substitution in the Drosophila homolog of the Jak kinase. Overactivity of the mutated protein is responsible for the malignant neoplasia. ${ }^{[40,41]}$

\section{Constitutively Activated Stat Proteins in Acute Leukemia}

Nuclear extracts derived from patients with acute lymphoblastic leukemia (ALL) and acute myeloid leukemia (AML) were examined for their content in Stat-DNA binding activity by using specific oligonucleotide probes and antibodies for Stat protein studies in bandshift assays. Stat-DNA binding complexes were detected with oligonucleotide probes including the $\gamma$-activation sequence (GAS) present in the IRF-1 gene promoter or with the MGF(mammary gland factor)/Stat 5 binding site of the $\beta$-casein gene promoter ${ }^{[35]}$ The formation of the complexes occured without in vitro cytokine cell stimulation before nuclear protein extraction (Fig. 1). Stat proteins need to be phosphorylated before they translocate to the nucleus and bind to DNA. This implied that the Stat 


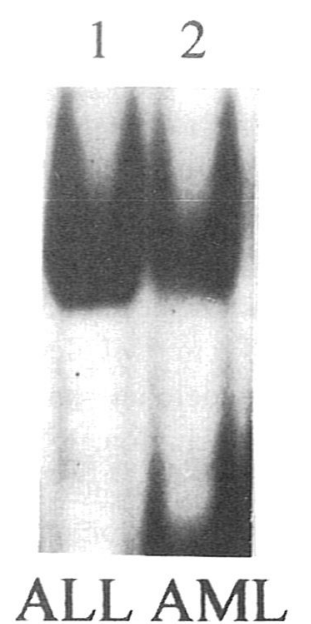

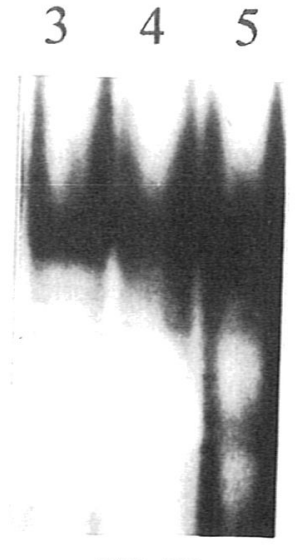

CML

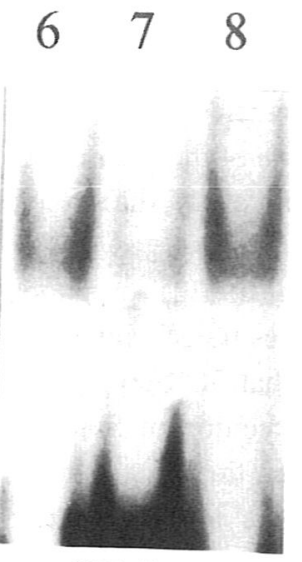

CLL

\section{Probe: $\beta$-casein}

FIGURE 1 Bandshift analysis of nuclear extracts from cells isolated from peripheral blood of patients with ALL, AML (lanes 1-2) with CML (lanes 3-5) and with CLL (lanes 6-8). $10 \mu \mathrm{g}$ of proteins were introduced into each binding reaction and incubated with the $\beta$-casein oligonucleotide probe.

proteins detected in nuclear extracts from ALL and AML cells were constitutively phosphorylated.

\section{Stat1, Stat 3 and Stat5 are Activated in Leukemic Cells}

The results obtained with MGF/Stat5 binding site sequence present in $\beta$-casein gene promoter and the GAS of the IRF-1 gene as probes for bandshifts suggested that Stat1, Stat 3 and Stat 5 related proteins were possibly involved in the formation of the complexes. These data were confirmed by supershift experiments using specific antibodies directed against different members of the Stat protein family.

Two parallel studies performed on nuclear protein extracts from primary cells of patients with acute leukemia show that Stat1, Stat 3 and Stat 5 can be constitutively activated. ${ }^{[34,35]}$ Stat 3 and Stat 1 activated proteins are preferentially detected in AML while Stat5 is mainly activated in ALL. However Stat 3 and Stat 1 can also be activated in some ALL and Stat5 in some AML. It would be of interest to study each profile of Stat protein activation with regard to cytogenetic abnormalities and/or immunological marker expression.
Constitutive phosphorylation of Stat5 was shown in ALL by immunoprecipitation of tyrosine phosphorylated proteins with anti phospho-tyrosine antibody followed by Western blot analysis with anti-Stat5 antibody. Confocal microscopy localized the Stat5 protein to the nucleus of the leukemic cells from patients with ALL. ${ }^{[34]}$ This particular localization of the protein supports the previous demonstration of the presence of activated Stat proteins in leukemic cells.

\section{Mechanisms Possibly Involved in Stat Protein Activation in Leukemia}

The mechanisms by which the Stat proteins are activated in ALL and AML remain to be clarified. Cytokine overproduction, some viral infections, chromosomal translocation can be evoked for Stat activation in leukemia. BCR/abl protein arises from $t(9,22)$ translocation and is present in chronic myelogenous leukemia (CML) as a $210 \mathrm{kDa}$ form of $\mathrm{BCR} / \mathrm{abl}$ and in some ALL as a $190 \mathrm{kDa}$ form of BCR/abl. K562 cell line is derived from patient with CML and expresses the BCR/abl translocation. In this cell line, Stat5 is constitutively activated. ${ }^{[34]}$ We investigated the Stat- 
DNA binding activity in nuclear cell extracts from different patients with CML. The protein extracts formed complexes with oligonucleotide probes containing the MGF/Stat5 binding site of the $\beta$-casein gene promoter (Fig. 1). In our previous study, the strongest Stat5 constitutive activation was observed in nuclear extracts from an ALL with $\mathrm{t}(9,22)$ translocation. Using hematopoietic cell lines transformed with BCR/abl, it has been established that BCR/abl strong kinase activity leads to phosphorylation of Stat 1 and Stat5 proteins. ${ }^{[42,43]}$ All together, these data show that BCR/abl protein can participate to Stat protein activation. Constitutively activated Stat proteins are also observed in nuclear extracts from patients with chronic lymphoblastic leukemia (CLL) (Fig. 1). These cells do not exhibit BCR/abl protein. Alternative pathway for Stat activation in CLL is probable.

The participation of viral infection in basal activity is hypothesized by different studies. T-cells transformed with human T-cell lymphotropic virus-1 (HTLV-1) exhibit constitutive activation of the JakStat pathway. IL-2-independent growth acquired by cells transformed with HTLV-1 correlates to acquisition of the constitutively activated JAK-Stat pathway. ${ }^{[44,45]}$ Whether this constitutive activation is a cause or a consequence of the pathology is not clear but acquisition of cytokine independent growth may participate to leukemogenesis.

The activation through phosphorylation can happen at different level of the cascad of the signaling pathway. Meydan et al. have shown that leukemic cells from patients with ALL in relapse have constitutively activated Jak2 protein tyrosine kinase. They demonstrated that the AG490 specific tyrosine kinase blocker selectively inhibits in vitro cell proliferation of leukemic cells. ${ }^{[46]}$ Overactivity of the tyrosine kinase might be responsible for Stat activation in some leukemia.

\section{Biochemistry of the Stat Proteins Constitutively Activated in Acute Leukemia}

In our previous paper, we suspected the existence of a shorter form of the Stat3 protein constitutively activated in leukemic cells. Because Stat 3 related proteins were recognized by an antibody directed against amino acids 688 to 727 but not by an antibody raised against amino acids 750 to 769 of the carboxyl-terminal domain, we concluded for the existence of Stat3 related factors with truncated or modified carboxylterminal region. ${ }^{[35]}$ Recently, Chakraborty et al. have reported the presence of $\operatorname{Stat} 3 \alpha$ (p92) and its spliced form Stat $3 \beta$ (p83) in AML derived cell lines by using the Stat3 monoclonal antibody (Transduction Laboratories, Lexington, KY) recognizing the $\mathrm{N}$ terminal part of the protein. ${ }^{[47]}$ By studying the effect of G-CSF on the activation of Stat 3 isoform proteins, they have shown that G-CSF did not activate Stat $3 \alpha$ in CD34+ bone marrow normal cells and HL60 cells, both reported to differentiate in response to G-CSF. In contrast, Stat $3 \alpha$ is activated by G-CSF in all AML cell lines tested and in 2 out of 5 uncultured AML patients samples. They suggest that the balance of the two Stat 3 isoforms in myeloid cells may influence the cellular pattern of gene activation and differentiation in response to G-CSF. ${ }^{[47]} \mathrm{We}$ analysed whole cell extracts from 8 AML in Western blot, with the Stat3 monoclonal antibody (Transduction Laboratories, Lexington, KY). Stat $3 \alpha$ and Stat $3 \beta$ were detected in all the samples tested. However, the level of the two proteins varies from patients to patients (Fig. 2). Whether this pattern is associated with the degree of cell differentiation or with characteristic immunological profiles of leukemia has still to be clarified with higher number of samples.

Constitutively activated Stat 5 related proteins have been detected in nuclear extracts of cells collected from some patients with ALL. ${ }^{[34,35]}$ The complexes formed with the extracts were supershifted by an antibody directed against the amino-terminal part of Stat5. ${ }^{[35]}$ Experiments performed with antibodies directed against the carboxyl-terminal domain of Stat5a and Stat5b were inefficient to supershift the complexes. These data are consistent with the possible existence of Stat 5 variants in acute leukemic cells. Further studies are needed to characterize these molecules. Naturally existing spliced variants of Stat5a and Stat $5 \mathrm{~b}$ have been described and cloned from different cell populations. ${ }^{[23,48]}$ These variants are also phosphorylated in response to cytokines. However, their 


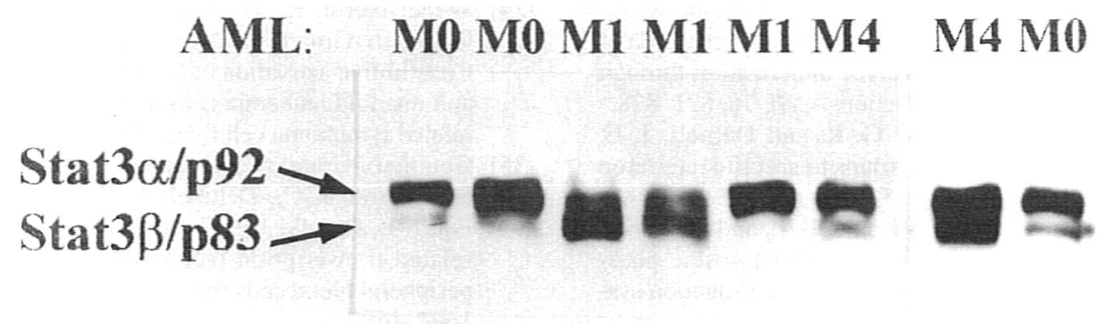

FIGURE 2 Protein extracts were derived from cells isolated from patients with AML. The French-American-British classification of the AML samples included M0, M1 and M4. Whole cell extracts (100 $\mu \mathrm{g})$ were separated by SDS-PAGE, blotted onto nitrocellulose and developed with the Stat 3 monoclonal antibody (Transduction Laboratories, Lexington, KY). This antibody recognizes both Stat $3 \alpha$ and Stat $3 \beta$. Immunoreactive bands were visualized using a chemiluminescence (ECL) Western blotting kit (Amersham).

dephosphorylation is delayed compared to the non spliced proteins. Delayed dephosphorylation might explain the detection of short forms of Stat proteins in the DNA binding complexes of leukemic cells.

The spliced variants have dominant negative phenotype on gene transcription. Inappropriate activation of Stat protein variants in acute leukemic cells might inhibit some genes important in cell cycle regulation or differentiation. Stat proteins and their variants are expressed in normal cells as well as in leukemic cells. However, the conditions of activation of both protein isoforms in leukemic cells might differ from normal cells and contribute to leukemogenesis.

\section{Acknowledgements}

We thank Dr. J. Rochette for his helpful suggestions and Marion Faucourt for her technical support. This work was supported by the "Association pour la Recherche Contre le Cancer".

\section{References}

[1] Shuai, K., Schindler, C., Prezioso, V. R. and Darnell, J. E. (1992). Activation of transcription by IFN- $\gamma$ : tyrosine phosphorylation of a 91-kD DNA-binding protein. Science, 258, $1808-1812$.

[2] Schindler, C., Fu, X. Y., Improta, T., Aebersold, R. and Darnell, J. E. (1992). Proteins of transcription factor ISGF-3: One gene encodes the 91- and 84-kDa ISGF-3 proteins that are activated by interferon $\alpha$. Proc. Natl. Acad. Sci. USA, 89, 7836-7839.

[3] Fu, X. Y., Schindler, C., Improta, T., Aebersold, R. and Darnell, J. E. (1992). The proteins of ISGF-3, the interferon alpha-induced transcriptional activator, define a gene family involved in signal transduction. Proc. Natl. Acad. Sci. USA, 89, 7840-7843
[4] Zhong, Z., Wen, Z. and Darnell, J. E. (1994). Stat3: a STAT family member activated by tyrosine phosphorylation in response to epidermal growth factor and interleukin-6. Science, 264, 95-98.

[5] Akira, S., Nishio, Y., Inoue, M., Wang, X.-J., Wei, S., Matsusaka, T., Yoshida, K., Sudo, T., Naruto, M. and Kishimoto, T. (1994). Molecular cloning of APRF, a novel IFNstimulated gene factor 3 p91-related transcription factor involved in the gp 130-mediated signaling pathway. Cell, 77, 63-71.

[6] Yamamoto, K., Quelle, F. W., Thierfelder, W. E., Kreider, B. L., Gilbert, D. J., Jenkins, N. A., Copeland, N. G., Silvennoinen, O. and Ihle, J. N. (1994). STAT4, a novel gamma interferon activation site-binding protein expressed in early myeloid differentiation. Mol. Cell. Biol., 14, 4342-4349.

[7] Wakao, H., Gouilleux, F. and Groner, B. (1994). Mammary gland factor (MGF) is a novel member of the cytokine regulated transcription factor gene family and confers the prolactin response. EMBO J., 13, 2182-2191.

[8] Mui, A. L. F., Wakao, H., O'Farrell, A. M., Harada, N. and Miyajima, A. (1995). Interleukin-3, granulocyte-macrophage colony stimulating factor and interleukin-5 transduce signals through two STAT5 homologs. EMBO J., 14, 1166-1175.

[9] Hou, J., Schindler, U., Henzel, W. J., Ho, T. C., Brasseur, M. and McKnight, S. L. (1994). An interleukin-4-induced transcription factor: IL-4 Stat. Science, 265, 1701-1706.

[10] Quelle, F. W., Shimoda, K., Thierfelder, W., Fischer, C., Kim, A., Ruben, S. M., Cleveland, J. I., Pierce, J. H., Keegan, A. D., Nelms, K., Paul, W. E. and Ihle, J. N. (1995). Cloning of murine STAT6 and human STAT6, STAT proteins that are tyrosine phosphorylated in response to IL4 and IL3 but are not required for mitogenesis. Mol. Cell. Biol., 15, 3336-3343.

[11] Darnell, J. E., Kerr, I. M. and Stark, G. R. (1994). JAK-STAT pathways and transcriptional activation in response to IFNs and other extracellular signaling proteins. Science, 264, 1415-1421.

[12] Wilks, A. F. and Harpur, A. G. (1994). Cytokine signal transduction and the JAK family of protein tyrosine kinases. Bioessays, 16, 313-320.

[13] Taniguchi, T. (1995). Cytokine signaling through non receptor protein tyrosine kinases. Science, 268, 251-255.

[14] Ihle, J. N. (1996). Stats: signal transducers and activators of transcription. Cell, 84, 331-334.

[15] Briscoe, J., Guschin, D. and Müller, M. (1994). Just another signaling pathway. Current Biology, 4, 1033-1035.

[16] Ihle, J. N. (1996). The Janus protein tyrosine kinase family and its role in cytokine signaling. Advances in Immunology, 60, $1-35$. 
[17] Shuai, K., Horvath, C. M., Huang, L. H. T., Qureshi, S. A., Cowburn, D. and Darnell, J. E. (1994). Interferon activation of the transcription factor Stat91 involves dimerization through SH2-phosphotyrosyl peptide interactions. Cell, 76, 821-828.

[18] Heim, M. H., Kerr, I. M., Stark, G. R. and Darnell, J. E. (1995). Contribution of Stat SH2 groups to specific interferon signaling by the Jak-Stat pathway. Science, 267, 1347-1349.

[19] Greenlund, A. C., Farrar, M. A., Viviano, B. L. and Schreiber, R. D. (1994). Ligand-induced IFN $\gamma$ receptor tyrosine phosphorylation couples the receptor to its signal transduction system (p91). EMBO J., 13, 1591-1600.

[20] Xu, X., Sun, Y.-L. and Hoey, T. (1996). Cooperative DNA binding and sequence-selective recognition conferred by the STAT amino-terminal domain. Science, 273, 794-797.

[21] Horvath, C. M., Wen, Z. and Darnell, J. E. (1995). A Stat protein domain that determines DNA sequence recognition suggests a novel DNA-binding domain. Genes \& Dev, 9, 984-994.

[22] Schaefer, T. S., Sanders, L. K. and Nathans, D. (1995). Cooperative transcriptional activity of Jun and Stat $3 \beta$, a short form of Stat3. Proc. Natl. Acad. Sci. USA, 92, 9097-9101.

[23] Wang, D., Stravopodis, D., Teglund, S., Kitazawa, J. and Ihle, J. N. (1996). Naturally occurring dominant negative variants of Stat5. Mol. Cell. Biol., 16, 6141-6148.

[24] Schindler, C. and Darnell, J. E. (1995). Transcriptional responses to polypeptide ligands: the Jak-Stat pathway. Annu. Rev. Biochem., 64, 621-651.

[25] Moriggl, R., Gouilleux-Gruart, V., Jähne, R., Berchtold, S., Gartmann, C., Liu, X., Hennighausen, L., Sotiropoulos, A., Groner, B. and Gouilleux, F. (1996). Deletion of the carboxylterminal transactivation domain of MGF-Stat5 results in sustained DNA binding and a dominant negative phenotype. Mol. Cell. Biol., 16, 5691-5700.

[26] Henttinen, T., Levy, D. E., Silvennoinen, O. and Hurme, M. (1995). Activation of the signal transducer and transcription (STAT) signaling pathway in a primary $\mathrm{T}$ cell response. J. Immunol., 155, 4582-4587.

[27] Feldman, G. M., Chuang, E. J. and Finbloom, D. S. (1995). IgG immune complexes inhibit IFN- $\gamma$ induced transcription of the Fc $\gamma$ RI gene in human monocytes by preventing the tyrosine phosphorylation of the $\mathrm{p} 91$ (Stat1) transcription factor. J. Immunol., 154, 318-325.

[28] Abbas, A. K., Murphy, K. M. and sher, A. (1996). Functional diversity of helper T lymphocytes. Nature, 383, 787-793.

[29] Wang, F., Sengupta, T. K., Zhong, Z. and Ivashkiv, L. B. (1995). Regulation of the balance of cytokine production and the signal transducer and activator of transcription (STAT) transcription factor activity by cytokines and inflammatory synovial fluids. $J$. Exp. Med., 182, 1825-1831.

[30] Rajan, P., Stewart, C. L. and Fink, J. S. (1995). LIF-mediated activation of STAT proteins after neuronal injury in vivo. Mol. Neurosci., 6, 2240-2244.

[31] Jiang, C.-K., Flanagan, S., Ohtsuki, M., Shuai, K., Freedberg, I. M. and Blumenberg, M. (1994). Disease-activated transcription factor: allergic reactions in human skin cause nuclear translocation of STAT-91 and induce synthesis of keratin K17. Mol. Cell. Biol., 14, 4759-4769.

[32] Watson, C. J. and Miller, W. R. (1995). Elevated levels of Stat family of transcription factors in breast carcinoma nuclear extracts. BR. J. Cancer, 71, 840-845.

[33] Happ, B., Hynes, N. E. and Groner, B. (1993). Ha-ras and v-raf, but not int-2 and c-myc, interfere with the lactogenic hormone dependent activation of the mammary gland specific transcription factor MGF. Cell Growth and Differentiation, 4, 9-12.
[34] Weber-Nordt, R. M., Egen, C., Wehinger, J., Ludwig, W., Gouilleux-Gruart, V., Mertelsmann, R. and Finke, J. (1996). Constitutive activation of STAT proteins in primary lymphoid and myeloid leukemia cells and in Epstein-Barr virus (EBV)related lymphoma cell lines. Blood, 88, 809-816.

[35] Gouilleux-Gruart, V., Gouilleux, F., Desaint, C., Claisse, J.F., Capiod, J.-C., Delobel, J., Weber-Nordt, R., DusanterFourt, I., Dreyfus, F., Groner, B. and Prin, L. (1996). STAT related transcription factors are constitutively activated in peripheral blood cells from acute leukemia patients. Blood, $\mathbf{8 7}$, 1692-1697.

[36] Yu, C.-L., Meyer, D. J., Campbell, G. S., Larner, A. C., Carter-Su, C., Schwartz, J. and Jove, R. (1995). Enhanced DNA-binding activity of a Stat3-related protein in cells transformed by the Src oncoprotein. Science, 269, 81-83.

[37] Cao, X., Tay, A., Guy, G. R. and Tan, Y. H. (1996). Activation and association of Stat3 with Sre in v-Src-transformed cell lines. Mol. Cell. Biol., 16, 1595-1603.

[38] Danial, N. N., Pernis, A. and Rothman, P. B. (1995). JakSTAT signaling induced by the $v-a b l$ oncogene., Science, $\mathbf{2 6 9}$, 1875-1877.

[39] Pallard, C., Gouilleux, F., Benit, L., Cocault, L., Souyri, M., Levy, D., Groner, B., Gisselbrecht, S. and Dusanter-Fourt, I. (1995). Thrombopoietin activates a STAT5-like factor in hematopoietic cells. EMBO J., 14, 2847-2856.

[40] Luo, H., Hanratty, W. P. and Dearolf, C. R. (1995). An amino acid substitution in the Drosophila hop ${ }^{\text {Tum-l }}$ JAK kinase causes leukemia-like hematopoietic defects. EMBO J., 14, 1412-1420.

[41] Harrison, D. A., Binari, R., Nahreini, T. S., Gilman, M. and Perrimon, N. (1995). Activation of a Drosophila Janus kinase (JAK) causes hematopoietic neoplasia and developmental defects. EMBO J., 14, 2857-2865.

[42] Frank, D. A. and Varticovski, L. (1996). BCR/abl leads to the constitutive activation of Stat proteins, and shares an epitope with tyrosine phosphorylated Stats. Leukemia, 10, 1724-1730.

[43] Carlesso, N., Frank, D. A. and Griffin, J. D. (1996). Tyrosyl phosphorylation and DNA binding activity of signal transducers and activators of transcription (STAT) proteins in hematopoietic cell lines transformed by Bcr/Abl. J. Exp. Med., $183,811-820$

[44] Migone, T.-S., Lin, J.-X., Cereseto, A., Mulloy, J. C., O'Shea, J. J., Franchini, G. and Leonard, W. J. (1995). Constitutively activated Jak-STAT pathway in T cells transformed with HTLV-1. Science, 269, 79-81.

[45] Xu, X., Kang, S.-H., Heidenreich, O., Okerholm, M., O'Shea, J. J. and Nerenberg, M. I. (1995). Constitutive activation of different Jak tyrosine kinases in human $\mathrm{T}$ cell leukemia virus type 1 (HTLV-1) Tax protein or virus-transformed cells. $J$. Clin. Invest., 96, 1548-1555.

[46] Meydan, N., Grunberger, T., Dadi, H., Shahar, M., Arpaia, E., Lapidot, Z., Leeder, J. S., Freedman, M., Cohen, A., Gazit, A., Levitzki, A. and Roifman, C. M. (1996). Inhibition of acute lymphoblastic leukaemia by a Jak-2 inhibitor. Nature, 379, 645-648.

[47] Chakraborty, A., White, S. M., Schaefer, T. S., Ball, E. D., Dyer, K. F. and Tweardy, D. J. (1996). Granulocyte colony-stimulating factor activation of Stat $3 \alpha$ and Stat $3 \beta$ in immature normal and leukemic human myeloid cells. Blood, 88, 2442-2449.

[48] Rosen, R. L., Winestock, K. D., Chen, G., Liu, X., Hennighausen, L. and Finbloom, D. S. (1996). GranulocyteMacrophage Colony-Stimulating factor preferentially activates the $94-\mathrm{kD}$ STAT5A and an $80-\mathrm{kD}$ STAT5A isoform in human peripheral blood monocytes. Blood, 88, 1206-1214. 